\title{
SLC7A6 wt Allele
}

National Cancer Institute

\section{Source}

National Cancer Institute. SLC7A6 wt Allele. NCI Thesaurus. Code C118993.

Human SLC7A6 wild-type allele is located in the vicinity of $16 q 22.1$ and is approximately $37 \mathrm{~kb}$ in length. This allele, which encodes $\mathrm{y}+\mathrm{L}$ amino acid transporter 2 protein, plays a role in the internalization of dibasic amino acids. 